\title{
O TRIBUNAL DE CONTAS E AS APOSENTADORIAS
}

I - O Tribunal de Contas como órgão independente; II - Da natureza administrativa da apreciação da aposentadoria; III - Da não substitutividade das decisões do Tribunal; IV - Da não obrigatoriedade imediata da decisão; V - Das cautelas da Administração antes de acatar a decisão denegatória; VI - Da aposentadoria como ato complexo; VII - Conclusões

Ao Tribunal de Contas compete, nos termos constitucionais, o exame da legalidade das aposentadorias concedidas pela autoridade administrativa.

Portanto, logo que a aposentadoria é concedida, o processo respectivo deve necessariamente ser encaminhado à Corte de Contas, que verificará a sua adequação às normas legais e efetuará o registro correspondente.

O procedimento de apreciação das aposentadorias pelo Tribunal de Contas, apesar de aparentemente simples, encerra questões de grande complexidade constitucional, relativas à competência de cada órgão e ao relacionamento entre os Poderes, até hoje ainda não pacificadas.

A prática administrativa tem suscitado não poucas indagações e perplexidades, dentre as quais destaco: é indispensável o registro pelo Tribunal para a perfeição e plena eficácia da aposentadoria? Detém o Tribunal de Contas competência para anular ou alterar o ato concessório? Tem o aposentado direito à prévia e ampla defesa, na hipótese de cassação de sua aposentadoria em decorrência de decisão denegatória de registro? Qual é a autoridade coatora, na hipótese de ingresso de Mandado de Segurança contra aposentadoria já registrada? Está o Tribunal de Contas obrigado a registrar, uma a uma, todas as aposentadorias?

No presente trabalho, à luz da doutrina e jurisprudência pátrias, procurarei contribuir no esclarecimento dessas questões.

* Assessor Jurídico. Supervisor da Câmara Municipal de São Paulo. Em exercício junto ao Tribunal de Contas do Município de São Paulo.

R. Dir. Adm.,

Rio de Janeiro, 217: 135-150, jul./set. 1999 
Como é sabido, no nosso regime constitucional. os Poderes Legislativo, Judiciário e Executivo não se confundem nem se subordinam. mas se harmonizam. cada qual desempenhando, além de sua função precípua - legislar, julgar ou administrar - outras funções que a Constituição the outorga para uma mútua cooperação institucional.

Além de legislar, o Poder Legislativo tem, dentre outras atribuições, a de controle externo das atividades administrativas de todos os Poderes. Por tradição que data do medievo, o legislativo é o poder financeiro: a ele compete não só autorizar a cobrança de tributos e consentir nos gastos públicos. mas também tomar conta dos que usam do patrimônio em geral.'

Exerce esse controle externo em decorrência do princípio republicano que fundamenta e informa o nosso sistema constitucional: os bens, dinheiros e valores públicos são do povo, e em seu benefício devem ser aplicados².

Como salienta Hely Lopes Meirelles, "o controle externo visa a comprovar a probidade da Administração e a regularidade da guarda e do emprego dos bens, valores e dinheiros públicos, assim como a fiel execução do orçamento. É por excelência, um controle político de legalidade contábil e financeira, o primeiro aspecto a cargo do Legislativo; o segundo, do Tribunal de Contas." ${ }^{3}$

Após prever que o controle externo, a cargo do Congresso, será exercido com o auxilio do Tribunal de Contas, o art. 71 da Constituição Federal passa a enumerar as atribuições específicas do mencionado Tribunal: apreciar as contas prestadas anualmente pelo Presidente da República, mediante parecer prévio (inciso I); julgar as contas dos administradores e demais responsáveis por dinheiros, bens e valores públicos da administração direta e indireta (II); apreciar. para fins de registro, a legalidade dos atos de admissão de pessoal, bem como a das concessões iniciais de aposentadorias. reformas e pensões (III); realizar, por iniciativa própria ou de órgãos do Poder Legislativo, inspeções e auditorias em quaisquer dos Poderes (IV); aplicar aos responsáveis, em caso de ilegalidade da despesa ou irregularidade de contas, as sanções previstas em lei (VIII); assinar prazo para que o órgão ou entidade adote as providências necessárias ao exato cumprimento da lei, se verificada ilegalidade (IX); sustar, se não atendido, a execução do ato impugnado, comunicando a decisão ao Poder Legislativo (X); etc. As decisões do Tribunal de que resulte imputação de débito ou multa terão eficácia de título executivo (art. 71, § 39).

Da análise desses dispositivos, verifica-se que embora o Tribunal de Contas esteja inserido formalmente no Poder Legislativo. como órgão de auxílio, suas funções de co-participação no controle externo não se resumem à mera subordinação a este Poder.

I Cf. Manoel Gonçalves Ferreira Filho, Curso de Direito Constitucional, 1992, p. 138.

2 Cf. Geraldo Ataliba, República e Constituição, RT, 1985, p. 50.

3 Direito Administrativo Brasileiro, Malheiros Editores, 1995, p. 604. 
Como bem assinalou o Ministro Celso de Mello. no MS21.466-DF, "o regime de controle externo, institucionalizado pelo novo ordenamento constitucional, propicia, em função da própria competência fiscalizadora outorgada ao Tribunal de Contas da União, o exercicio, por esse órgão estatal, de todos os poderes que se revelem inerentes e necessários à plena consecução dos fins que lhe foram cometidos". 4

A maioria da doutrina pátria entende que o Tribunal de Contas, em razão de sua ampla competência constitucional, embora formalmente vinculado ao Legislativo, constitui órgão independente, exercendo funções que não se sujeitam à relação hierárquica com qualquer dos três poderes.

Com razão, afirma Odete Medauar que a Constituição, em artigo algum, utiliza a expressão "órgão auxiliar", mas sim que o controle externo do Congresso Nacional será exercido "com o auxílio do Tribunal de Contas", cuja natureza é de instituição estatal independente, sendo impossível considerá-lo subordinado ao Legislativo.'

Nesse sentido, Oswaldo Aranha Bandeira de Mello assevera que "na organização jurídica do Estado todos os órgãos são de igual importância no exercício das suas respectivas funções, cada uma imprescindivel ao Estado de Direito. E de tal realce é a do Tribunal de Contas, que se encontra fora da concepção tríplice dos três poderes, e a quem cabe a fiscalização econômico-financeira de todos eles. ${ }^{\circ}$

Eduardo Botelho Lobo Gualazzi, por seu turno, salienta que "o Tribunal de Contas é o órgão administrativo que constitucional e legalmente exerce, em relação aos três poderes do Estado, competências técnico-específicas de controle administrativo externo, exclusivas, privativas e indelegáveis.?

E conclui com precisão Hely Lopes Meirelles: "inútil e ociosa se nos afigura a discussão sobre a qual dos Poderes pertence ou deve pertencer o Tribunal de Contas, pois, como órgão independente, não se subordina a nenhum deles, visto que a nenhum está hierarquizado, tanto assim que se auto-organiza e a todos controla". .

Com o fim de que os Ministros ou Conselheiro do Tribunal de Contas pudessem desempenhar com isenção essas atribuições independentes e relevantes, a Constituição da República, no art. $73, \S 3$ 으, assegurou-lhes a autonomia funcional, através das garantias e prerrogativas próprias da magistratura.

\section{II - Da natureza administrativa da apreciação da aposentadoria}

Dentre as atribuições que exerce com independência, sem qualquer subordinação ao Legislativo, está a de apreciar a legalidade dos atos de concessão das aposentadorias.

4 RTJ 153/151.

5 Controle da Administração Pública, RT, 1993, p. 141.

6 Tribunais de Contas-Natureza, Alcance e Efeitos de suas funçöes, RDP 73/181.

7 Regime Jurídico dos Tribunais de Contas, Ed. RT, 1992, p. 187.

8 Auditoria do Tribunal de Contas em Departamento de Despesa de Câmara Municipal, RT 532/35-46. 
Acertadamente afirma Wolgran Junquira Freira que. com relação a essa função do Tribunal de Contas, "não coopera ele com o Congresso Nacional, como o faz. em relação ao controle externo da fiscalização financeira e orçamentária. Decide. julga e define direitos, sem apelo ao Congresso Nacional." "

Por interessar-nos mais de perto, convém transcrever o texto do art. 71, inciso III. da Constituição Federal:

“Art. 7I. O controle externo, a cargo do Congresso Nacional, será exercido com o auxílio do Tribunal de Contas da União, ao qual compete:

$I$ - (omissis)

II - (omissis)

III - apreciar, para fins de registro, a legalidade dos atos de admissão de pessoal, a qualquer titulo, na administração direta e indireta, incluidas as fundações instituidas e mantidas pelo Poder Público, excetuadas as nomeações para cargo de provimento em comissão, bem como a das concessōes de aposentadorias, reformas e pensões ressalvadas as melhorias posteriores que não alterem o fundamento legal do ato concessório." (grifo nosso)

Trata-se de apreciação que consiste em um verdadeiro julgamento administrativo, de competência exclusiva da Corte de Contas.

Pereira Lira, em antigo voto como Ministro do TCU, já distinguia, por um lado, "o campo de atuação do Tribunal como órgão auxiliar do Congresso", como auxiliar técnico no acompanhamento da execução orçamentária, e de outro lado, "a área, bem distinta, em que a Corte exercia uma competência privativa, proferindo julgados somente suscetíveis de revisão pela via judicial". Nessa última área, no seu entender, conforme texto inovador da Constituição de 1946, incluía-se a de julgar da legalidade das aposentadorias, reformas e pensões." $1 "$

Pontes de Miranda, em seus Comentários à Constituição de 1946, já defendia na época que " a atribuição de julgamento da legalidade dos contratos e das aposentadorias, reformas e pensões é somente para eficácia administrativa. A inconstitucionalidade ou ilegalidade pode ser levada à apreciação do Poder Judiciário.". E Seabra Fagundes comentando a nova previsão constitucional, também esclarecia: " a atribuição que desempenha ( $O$ Tribunal de Contas) é materialmente administrativa... A intervenção para registro não diz definitivamente da juridicidade do ato", prerrogativa do Poder Judiciário."

Portanto, logo após a inclusão dessa atribuição inovadora, fixou-se o entendimento de que o julgamento das aposentadorias teria natureza administrativa e não jurisdicional.

É certo que houve, no passado, certa perplexidade quanto à natureza de outras decisões exaradas por esse órgão de controle externo, por exemplo quanto ao julgamento dos responsáveis pelos bens e dinheiros públicos, mas hoje em dia o tema já

9 Comentários à Constituição de 1988, Ed. Julex, 1989, vol. 2, p. 620.

10 Registro sob reserva - Aposentadoria, Reforma e Pensōes, RDA 82/232.

II apud Carlos Casimiro Costa, Funções Jurisdicionais e Administrativas dos Tribunais de Contas, RDA 53/29-55, 34. 
está pacificado na doutrina e na jurisprudência. no sentido de que nenhuma das tarefas ou atividades do Tribunal de Contas configura atividade jurisdicional."

A nossa ordem constitucional adota o sistema da unicidade de jurisdição, de maneira que nenhuma lesão de direito poderá ser excluída da apreciação pelo Poder Judiciário (art. 5, XXXV). Em consequiência, ausente nas decisões do Tribunal de Contas, ainda que transitadas em julgado, o caráter de definitividade ou imutabilidade próprias da coisa julgada judicial. ${ }^{13}$

A apreciação do ato concessório da aposentadoria, consiste, pois, em um julgamento administrativo, em uma verificação da sua legalidade do ato da Administração. Decidindo que o ato está conforme o Direito, o Tribunal de Contas efetuará o seu registro; caso contrário, o denegará.

\section{III - Da não substitutividade das decisões do Tribunal}

Embora dotada de natureza administrativa, a decisão da Corte de Contas sobre o registro não substitui o ato concessório da aposentadoria, por não consistir em controle interno. Tampouco detém o caráter substitutivo da jurisdição judicial.

Victor Nunes Leal, baseando-se em ensinamentos de Castro Nunes e Themístocles Cavalcanti, assevera não ser possível a confusão da Corte de Contas, órgão estranho à administração, com as instâncias administrativas que funcionam como órgãos subordinados do Poder Executivo. ${ }^{14}$

Conforme Súmula 473 do STF, como põe em relevo Hely Lopes Meirelles, a Administração tem competência para, através do controle interno, anular, revogar ou alterar seus próprios atos, em virtude do poder-dever de autotutela. Esse controle é normalmente exercido pelos órgãos superiores sobre os inferiores (controle hierárquico próprio das chefias e corregedorias), com auxilio de órgãos incumbidos do julgamento de recursos (controle hierárquico impróprio), ou, ainda, de órgãos especializados em determinadas verificações (controle técnico de auditorias etc.), mas integrantes da mesma Administração, pelo quê se caracteriza como controle interno, pois que o externo é sempre atribuido a órgão estranho ao Executivo." 15

$\mathrm{Na}$ atuação do controle interno, é possível a substituição do ato controlado pela decisão do órgão controlador, já que "o superior dispõe do poder de substituir ou corrigir o inferior, em matéria de competência comum". 16

12 J. Cretella Júnior, Natureza das Decisōes do Tribunal de Contas, RT 631/14-23; Maria Sylvia Zanella Di Pietro, Coisa Julgada - Aplicabilidade a decisōes do Tribunal de Contas da Uniāo, Rev. TCU v. 27, n 70/23-36, e A. J. Ferreira Custódio, Eficácia das Decisões dos Tribunais de Contas, RT 685/7-14.Dentre os julgados, citem-se RT 224/345, 253/330, 357/466, RDA 47/182, 48/307 e 63/215; RTJ 45/748 e 77/29.

13 Cf. A. C. Araújo Cintra; Ada P. Grinover e Cândido R. Dinamarco, Teoria Geral do Processo, Ed. RT, 1991, p. 119.

14 Valor das Decisōes do Tribunal de Contas, RDA 12/418-431.

15 Direito Administrativo Brasileiro, op. cit., p. 575.

16 Lafayette Pondé, op. cit. p. 44. 
Contudo. sendo o Tribunal de Contas órgão de controle externo. estranho à Administração. não detém competência para substituir ou realizar qualquer alteração no ato concessório.

$\mathrm{Na}$ esteira desse princípio, o Supremo Tribunal Federal tem se manifestado reiteradamente no sentido de que o Tribunal de Contas "só tem uma alternativa: ou julga válida a aposentadoria voluntária nos termos em que foi concedida, ou a julga nula, por ilegal. O que não pode é determinar o registro da aposentadoria em termos diversos dos em que foi ela requerida e deferida. ${ }^{17}$. E que "no desempenho dessa especifica atribuição, não dispõe de competência para proceder a qualquer inovação no tírulo jurídico de aposentação submetido a seu exame." IR

Por outro lado, justamente por ser de natureza administrativa e não judicial, a decisão sobre o registro não se reveste da substitutividade própria da "res judicata".

Como ensina Celso Ribeiro Bastos, "ao próprio particular (ou até mesmo a pessoas jurídicas de direito público), o Estado subtraiu a faculdade de exercício de seus direitos pelas próprias mãos. O lesado tem de comparecer diante do Poder Judiciário, o qual, tomando conhecimento da controvérsia, se substitui à própria vontade das partes que foram impotentes para se autocomporem." ${ }^{19}$. E recorda a seguir a lição de Arruda Alvim, "in verbis":

"Evidentemente tem-se que distinguir a atividade jurisdicional da administrativa e legislativa. As duas últimas, especialmente a administrativa, consistem em atuação em conformidade com a lei, mas são nitidamente diversas da atividade jurisdicional, pois esta é atividade secundária ou substitutiva, ao passo que a administrativa é primária" 20

Deve-se concluir, portanto, que as decisões da Corte de Contas não têm poderes para substituir, anular, retificar ou convalidar o ato concessório de aposentadoria, mas apenas "reconhecem, chancelam ou atestam aquilo que encontram(...), sem acrescer, subtrair ou alterar." 21

IV - Da não obrigatoriedade imediata da decisão

Certo que o Tribunal de Contas "é sobranceiro à própria administração", conforme voto de Castro Nunes no STF"2, e que suas determinações "são obrigatórias para os órgãos da Administração." "23. Maria Sylvia Zanella Di Pietro entende que a decisão da Corte de Contas é "final para a administração" e "faz coisa

17 MS 20.038, RTJ 80/394; Recl. 3.825/190, RT 698/247.

18 MS 21.466, RTJ 153/151.

19 Curso de Direito Constitucional, Saraiva, 1992, p. 315.

20 Curso de Direito Processual Civil, RT, v. 1, p. 149).

21 Rodolfo de Camargo Mancuso, Sobre a Execuçāo das decisões proferidas pelos Tribunais de Contas, especialmente a legitimação, RT 743/74.

22 RDA 7/212.

23 RE 74.663-SP, RTJ 65/500. 
julgada, não só no sentido assinalado para coisa julgada administrativa (preclusão da via administrativa. por não cabimento de qualquer recurso), mas também e principalmente no sentido de que ela deve ser necessariamente acatada pelo órgão administrativo controlado, sob pena de responsabilidade, com a única ressalva para a possibilidade de impugnação pela via judicial." „^

O Ministro Rodrigues Alckmin, em voto no MS 19.973 assevera que a decisão quanto ao registro das aposentadorias "é definitiva na esfera da administração, insuscetivel de subordinar-se à determinação outra do Presidente da República e irrevisivel pelo Congresso Nacional." 25

Contudo, tais afirmações devem ser entendidas "cum grano salis", com certas ressalvas.

Primeiramente, importa distinguir as decisões que resultam na imputação de débito ou multa, com eficácia de título executivo (art. 71, II e $\S 3^{\circ}$ da C.F. ), e as decisões relativas às aposentadorias (art. 71, III da C.F.).

Quanto a essas últimas, é preciso levar em conta que consistem em uma verificação de legalidade, de efeito meramente declaratório, e não constitutivo, condenatório ou mandamental, como leciona Rodolfo de Camargo Mancuso ${ }^{26}$

Assim, limitam-se a eliminar ou resolver a incerteza do direito ou de uma relação jurídica, com o consequiente registro dos atos examinado, caso se conclua pela legalidade - ou, se dẹtectada ilegalidade, pela denegação do registro. Não têm por fim determinar um comando imediato à Administração ou ao agente responsável, nem efetuar qualquer condenação.

Inegável que existe a obrigatoriedade da Administração conformar os seus atos com as decisões do Tribunal de Contas, em face da especifica competência constitucional deste órgão. A decisão deste órgão de controle externo, evidentemente, não traduz uma mera opinião ou simples aconselhamento. Terá efeitos impositivos embora não imediatos - não só para o agente que concedeu a aposentadoria como para a Administração como um todo, responsável última pelo ato concessório.

A Administração, como Poder constitucional independente, caso não se convença da força jurídica dos argumentos esposados pelo Tribunal de Contas, tem o poder-dever de se valer dos remédios administrativos ou judiciais pertinentes, com o fim de reformar a decisão questionada e de fazer prevalecer o próprio entendimento sobre a matéria.

Tal convencimento da Administração, no mesmo sentido ou em sentido contrário ao do Tribunal de Contas, assume relevante importância na medida em que norteará a sua atuação não apenas no processo que sofreu glosa pelo Tribunal, mas em todos os processos de aposentadoria cujos servidores se encontrem em situação análoga ou similar.

Oportuna a manifestação do Ministro Marco Aurélio de Mello, do STF, no Conflito de Atribuições n 40: "A concessão de aposentadoria ao servidor público,

24 op. cit. pp. 31 e 35.

25 RTJ 77/29.

26 op. cit., p. 77. 
em sentido lato, insere-se na atribuição constitucional e legal de cada Poder competente para a nomeação (...) O pronunciamento da ilegalidade da aposentadoria impõe-se ordinariamente à observância do órgão ou entidade que a concedeu, pela força de convencimento jurídico das próprias decisóes emanadas do Tribunal de Contas da União, órgão estatal constitucionalmente qualificado para o controle desse e de outros atos da Administração." 27

Por outro lado, conforme já amplamente exposto, o Tribunal de Contas, é órgão independente no exercício de suas funções, embora formalmente vinculado ao Poder Legislativo e participe, junto com esse Poder, do controle externo. O controle do Tribunal de Contas sobre os atos da Administração não é um controle vertical, onde há um órgão superior e outro inferior subordinado, mas é um "controle horizontal interorgânico", como leciona Jorge Silva Censio ${ }^{28}$. É um controle entre "órgãos constitucionais", os quais, assevera Anna Cândida da Cunha Ferraz, "não estão ligados entre si por relação hierárquica, mas que vem estabelecidos na própria norma fundamental, em um mesmo nivel de separação funcional; trata-se destarte, de um controle interorgânico, horizontal" ${ }^{29}$.

Eis por que a decisão da Corte de Contas, embora obrigue a Administração, não poderá ser simplesmente acatada como se fosse proferida por órgão hierarquicamente superior, ou como se dotada da força e da definitividade da coisa julgada judicial.

Entendo, pois, que assiste razão a Eros Roberto Grau, ao asseverar que as decisões sobre a legalidade das aposentadorias "não obrigam imediatamente a Administração", sem embargo de poderem ensejar, caso desatendidas, a sustação do ato concessório pela Corte de Contas, com base inciso $\mathrm{X}$ do art. 71 da Constituição. ${ }^{30}$

Porém, diferentemente do douto professor, que fundou a não obrigatoriedade imediata destas decisōes no fato de o Tribunal de Contas ser mero órgão auxiliar do Legislativo - titular único do controle externo - entendo serem outros os fundamentos da ausência de imediatidade.

Conforme já assinalado, os fundamentos da não obrigatoriedade imediata das decisões do Tribunal de Contas sobre as aposentadorias estariam no seu efeito meramente declaratório, bem como no princípio de independência entre os Poderes e conseqüente não subordinação hierárquica da Administração em relação à decisão do órgão de controle externo.

\section{V - Das cautelas da Administração antes de acatar a decisão denegatória}

Na hipótese de ocorrer denegação de registro pela Corte de Contas, a Administração, antes de anular ou retificar o ato concessório, deverá tomar algumas cautelas, dentre as quais se destacam: a) verificar se o aposentado já apresentou defesa sobre

RTJ 149/323, p. 326.

28

intración, RDP 39/5-19, 9.

30

Conflito entre Poderes, RT, 1994, p. 152.

Tribunal de Contas-Decisão-Eficácia, RDA 210/351-356. 
as ilegalidades que motivaram a denegação; b) alterar o seu convencimento sobre a matéria ou recorrer ao Poder Judiciário para fazê-lo prevalecer - com a sua irrenunciável independência constitucional - , de sorte que, a final, venha adotar posicionamento coerente e uniforme sobre a matéria, extensível a todos os casos similares ou análogos.

Como se sabe, em virtude do restrito âmbito do exame que constitui o controle externo, o aposentado não é ordinariamente chamado a participar do processo respectivo.

O Pleno do STF na Suspensão de Segurança 514(AgRg), entendeu que o Tribunal de Contas, no julgamento da legalidade das aposentadorias, não está jungido a um processo contraditório ou contencioso."' E o Ministro Octávio Gallotti, que com brilhantismo integrara o Tribunal de Contas da União, ao relatar no STF o MS 21.449-SP, v.u. em 27.09.95, portanto na vigência da atual Constituição, asseverou, quanto ao princípio da ampla defesa: "ordinariamento do procedimento de registro não participa o administrado, não cabendo invocar o referido princípio" ${ }^{32}$ Recordou o Ministro, na ocasião, a lição do Professor Sebastião Baptista Affonso:

" $O$ registro das concessões de pensões, como de aposentadorias e reformas, $e$ ainda o dos atos de admissão de pessoal (art. $7 \mathrm{l}, \mathrm{III}$, da Constituição) é uma atividade de auditoria, assinalada pelo caráter exaustivo do controle da legalidade. Desenrola-se, o respectivo procedimento, entre os órgãos de fiscalização e os de gestão, sem margem para a participação ativa de eventuais credores da Fazenda, que possam vir a sofrer efeitos das glosas ou correções impostas."

Esse posicionamento foi reiterado no RE 163.301-8-AM, julgado em 21.10.97, em que o Relator, Ministro Sepúlveda Pertence, na esteira de parecer no mesmo sentido exarado pelo Procurador Geral Aristides Junqueira no AGSS 514, RTJ 150/403, concluiu que "não parece razoável cogitar-se de inobservância do contraditório, vez que se trata aqui de procedimento unilateral do Tribunal de Contas na apreciação da legalidade, sem necessidade de intervenção do interessado." ${ }^{33}$

De acordo com a jurisprudência pátria, portanto, a fiscalização do Tribunal sobre as aposentadorias dirige-se sobre o ato concessório, a fim de verificar a conformidade com os princípios legais, e somente ao agente responsável, e não ao aposentado, é assegurada a ampla defesa.

Ora, de acordo com a Constituição em vigor, especialmente em seu art. 5, inciso LV, injurídica a imposição ao administrado de qualquer restrição, gravame ou sanção, sem que se lhe abra a oportunidade de exercer a ampla defesa. ${ }^{34}$

A jurisprudência orienta-se tranqüilamente por esse diapasão. ${ }^{35} \mathrm{Em}$ razão do art. 5, LV, da Constituição Federal, " a possibilidade da Administração anular seus próprios atos, de forma singular, só prevalece quando não conferiu direitos a

31 RTJ 150/402.

32 RTJ 163/116.

33 RT $751 / 194$.

34 Hely Lopes Meirelles, Direito Administrativo Brasileiro, op. cit., p. 590.

35 MS 28.861.0, TJESP, Pleno. V.u., Rel. Des. Nelson Schiesari, j. 13.03.96. 
terceiros: nesta última hipótese só poderá fazê-lo por meio regular, possibilitando aos beneficiados a ampla defesa." "३n

Em consequiência, a Administração, antes de cassar ou alterar o ato concessório. está obrigada a assegurar ao aposentado o direito de defesa.

Deverá ainda, como Poder independente que é. analisar detidamente a juridicidade da decisão denegatória do registro.

Discordando do entendimento da Corte de Contas. caso não seja mais admissível a interposição de recurso ou revisão administrativa, nos termos regimentais daquela Corte, necessitará a Administração recorrer ao Poder Judiciário, a fím de obter a sustação dos efeitos ou a anulação da decisão denegatória.

Se não recorrer à tutela jurisdicional, a não conformidade com a decisão do Tribunal transitada em julgado, entre outras consequiências, poderá acarretar a responsabilização do agente público, inclusive através de tomada de contas especial (art. 189 do Regimento Interno do Tribunal de Contas da União. Resolução Administrativa no 15 . de 15 de junho de 1993), uma vez que a decisão denegatória do registro é inequivocamente obrigatória e final na esfera administrativa.

Conforme todo o exposto, a Administração jamais pode ser considerada subordinada ou mera executora material da decisão do Tribunal de Contas quanto às aposentadorias. Incumbe-lhe, na hipótese de denegação do registro, proferir uma nova decisão independente, de sua inteira competência e responsabilidade.

Atualmente, conforme jurisprudência pacífica do STF. se a autoridade administrativa acolhe, antes do julgamento do Tribunal de Contas. recomendação ou determinação deste Tribunal para retificar o ato concessório, é ela quem deve ser considerada coatora, em mandado de segurança impetrado pelo aposentado. Entende o Pretório Excelso que não está a autoridade administrativa obrigada a cumprir, como mera executora, a diligência nessa hipótese. Somente quando já ocorreu o julgamento do registro é que o Tribunal de Contas passa a deter legitimidade passiva "ad causam". 37

Parece-me, "data venia", que a autoridade administrativa deverá sempre ser a autoridade considerada como coatora, mesmo diante do julgamento pela denegação do registro, por ser ela a inteira responsável por alteração do ato concessório, mesmo que em decorrência de decisão do Tribunal de Contas.

De acordo com essa tese encontra-se Sérgio Ferraz, para quem os atos submetidos a controle não devem ser impetrados contra o órgão controlador, que não exara imediato comando, além de que será o órgão controlado quem disporá de uma forma eficaz de cumprir a prestação jurisdicional reclamada pelo impetrante. ${ }^{3 *}$

36 TJSP, $2^{\Perp}$ Cam. Dir. Publ., Apelação Cível n² 29.557-5, j. 30.06.98, Rel. Vanderci Álvares. No mesmo sentido, RT 725/214. Em sentido inverso, quando "rematada ofensa ao ordenamento constitucional", RE 185.255-1/AL, Min. Sydney Sanches, j. 1.04.97, RT 747/195.

37 MS 21.462-7-DF, DJU 29-4-94, RTJ 154/476; MS 21.683-2, DJU 16-12-94, RTJ 158/91; MS 21.466-DF, RTJ 153/151.

38 Mandado de Segurança, Malheiros Ed., 1996, pp. 59 e segs. 
O prazo para o ingresso do Mandado de Segurança - o mesmo se diga da ação ordinária objetivando o mesmo lïm - começará a ser contado a partir da publicação da aposentadoria ou da decisão da Administração que a altere, e não da data da sua apreciação pelo Tribunal de Contas. O STJ, em ação ordinária que visava alterar aposentadoria, já decidiu que "a partir da publicação do ato, pois, começa a correr a prescrição qüinqüenal da ação que tem por objeto alterá-lo, presente o princípio da 'actio nata', e não da decisão do Tribunal de Contas, que aprecia a sua legalidade $e$ que não pode, nessa atividade fiscalizadora, modificar o seu fundamento. ${ }^{39}$

\section{$\mathrm{VI}$ - Da aposentadoria como ato complexo}

Como se sabe, o ato complexo é um ato único, indiviso, embora resultante de um concurso de vontades de diferentes órgãos administrativos, e se aperfeiçoa com a manifestação do último órgão. "No ato complexo, as vontades dos órgãos se unem em uma só vontade para formar o ato; há identidade de conteúdo e de fins."

Porém, em face da não substitutividade e da não obrigatoriedade imediata da decisão de registro do Tribunal de Contas, bem como da independência constitucional e ausência de subordinação hierárquica da Administração ao órgão de controle externo, injurídica a tese de que a apreciação da aposentadoria integra e aperfeiçoa $o$ ato examinado.

Conforme se deduz até mesmo da simples leitura do art. 71, inciso III, da C.F., quando a aposentadoria é submetida a registro pela Corte de Contas não se vislumbram vontades que se revestem do mesmo conteúdo, ou visando aos mesmos fins. Um é o ato da aposentadoria, que já se pressupõe perfeito e acabado, e outro é o ato de controle externo, realizado "a posteriori", visando a objetivo completamente distinto.

Bem esclarece Lafayette Pondé: "o ato de controle não participa do ato controlado. É sempre um ato em confronto com este. Não há entre eles unificação de vontade nem de objetivos". Entende superada a doutrina que, no passado, via na colaboração do órgão de controle com o órgão controlado um ato complexo. Ressalta o autor existirem dois atos distintos, com diferentes efeitos jurídicos: " um a aposentadoria, ato decisório, de efeito externo, que desinveste o funcionário do serviço ativo e altera sua posição jurídica, o outro a aprovação, de efeito interno, sobre o decreto da aposentadoria, não sobre a relação funcional" + .

No mesmo sentido, conclui Carlos Schmidt de Barros Jr., para quem "näo parece integrar um ato complexo a manifestação de órgão de controle. $O$ ato sujeito a exame de órgão de controle é distinto do ato deste. Um e outro distinguem-se, permanecem autônomos, pelo conteúdo e fins diversos que objetivam. Essa distinção

39 STJ, Resp 1.560/RJ, Rel. Min. Carlos Velloso, $2^{\mathrm{a}}$ Turma, j. 28.11.90, DJ I de 25.02.91.

40 Cf. Hely Lopes Meirelles, Direito Administrativo Brasileiro, op. cit., p. 54.

41 Cf. Maria Sylvia Zanella Di Pietro, Direito Administrativo, 1999, p. 185.

42 Controle dos Atos da Administração Pública, RDA 212/41-47. 
procura Bielsa expressar quando explica que num caso há intervenção de ato de vontade (ato complexo), noutro, de ato de inteligência, ım processo racional, não volitivo." 43

Caio Tácito, nessa esteira, afirma: "o Tribunal não concede a aposentadoria, reforma ou pensão, nem tampouco lhes confirma ou ratifica a concessão. Apenas examina a legalidade do ato, para efeitos financeiros, registrando a despesa correspondente.(...) Não há, no sentido jurídico estrito, aprovação do ato da administração, mas, apenas, forma de controle da legalidade do ato acabado, cuja executoriedade fica suspensa até que se opere o julgamento do ente fiscalizador." $\$$

Em seu Curso de Direito Administrativo, Themístocles Cavalcanti manifesta-se no sentido de que "a exigência de registro não torna o ato complexo porque o registro é ato de controle da legalidade" ${ }^{45}$, posicionamento que reiterou quando Ministro do Supremo Tribunal Federal, no MS 15.164-BA ${ }^{\text {th }}$

Ademais, de acordo com o direito brasileiro e italiano, "o ato administrativo complexo, após o seu aperfeiçoamento pode ser visto como única vontade da Administração, posto que é modalidade de ato administrativo unilateral" ${ }^{47}$. Ora, o registro, sendo deferido por órgão independente de controle. jamais, a meu ver, poderá confluir com o ato da Administração, formando uma única vontade.

Mais adequado seria falar-se em atos simples distintos, e não em um único ato complexo. Em todo caso, apenas no tocante ao ato de registro, poder-se-ia reconhecer um procedimento de registro, através do qual é apreciada a legalidade da aposentadoria pela Corte de Contas. O procedimento administrativo, como é sabido, consiste em uma série de atos, com manifestações de vontades autônomas e finalidades próprias, tendentes a um provimento final. Nele "os atos sequienciados possuem objetivos próprios e efeitos autônomos." $+\$$

Oportuno, nesse sentido, o Parecer da Subprocuradora Geral Odília Ferreira da Luz Oliveira, acolhido pelo Procurador-Geral da República no MS n² 21.625-5-DF:

"Não há, no caso, ato complexo (ou composto, na terminologia do professor Oswaldo Aranha Bandeira de Mello). Isso porque o registro pelo Tribunal de Contas não integra a formação do ato de aposentadoria, nem é requisito de sua eficácia, mas simples forma de controle posterior (art. 71 , inciso III, da Constituição da República). Desde a publicação, o ato administrativo de concessão de aposentadoria, que já completou o ciclo de formação, também produz todos os seus efeitos: o servidor afasta-se definitivamente do exercicio das atribuiçōes do cargo e passa a receber os proventos, independentemente de

43 Revista da Procuradoria Geral do Estado, 1/46-53, 50.

44 Revisão Administrativa de Atos Julgados pelo Tribunal de Contas, RDA 53/216.

$458^{2}$ ed., $n^{2} 250$.

46 RTJ $45 / 756$.

47 Elival da Silva Ramos, Do ato administrativo complexo no direito italiano e brasileiro, Revista da Procuradoria Geral do Estado de São Paulo, vol. 32/173-177, 176.

48 Elival da Silva Ramos, op. cit., p. 177. 
qualquer manifestação do Tribunal de Contas. Por isso, a concessão de aposentadoria é, desde logo, passivel de controle jurisdicional, inclusive por mandado de segurança, que pressupõe ato eficaz, como é, desde a publicą̧ão,o ato em causa." $\$ 9$

É certo que há abundante jurisprudência considerando a aposentadoria registrada pelo Tribunal de Contas configuraria ato complexo. ${ }^{50}$ De acordo com essa orientação jurisprudencial posicionou-se no passado a Consultoria Geral da República. ${ }^{{ }^{\prime} t}$ bem como, recentemente, Sandra Julien Miranda, em alentada obra. 52

Outros, reconhecendo tratar-se de tema polêmico, preferem não posicionar-se definitivamente sobre a questão, como Arruda Alvim. ${ }^{53}$

Contudo, o Ministro Marco Aurélio de Mello, do Supremo Tribunal Federal, ao relatar o Conflito de Atribuições no 40-DF, em 3 de junho de 1993, adota, a meu ver, o posicionamento mais adequado:

"Ainda hoje não é pacifica a questão em torno da natureza jurídica do registro, se constitui ato que integra o ato de concessão de aposentadoria, para a formação de um ato único (ato complexo), ou se é autônomo de controle da legalidade, sem função integrativa, do qual depende a eficácia ou executoriedade definitiva do primeiro.

Parece-nos mais acertada esta última posição, já sustentada por Francisco Campos em 1926, segundo a qual o registro pressupõe acabado, integrado e perfeito o ato administrativo - já dotado de uma executoriedade provisória - correspondendo a uma função de controle, que não colabora na formação do ato, sendo apenas condição de sua executoriedade definitiva (Tribunal de Contas - Registro sob Protesto, in Direito Constitucional, 1956, vol. II, pág. 140). No mesmo sentido, entende Themistocles Cavalcanti que a exigência de registro nāo torna o ato complexo porque o registro é ato de controle da legalidade (voto no RMS n" 15.164-BA, RTJ 45, pág. 759)." ${ }^{54}$

Apenas ressalto que, no meu parecer, de acordo com o posicionamento acima mencionado da Procuradoria da República, não há que se falar em executoriedade provisória. A aposentadoria, logo que concedida pela Administração, reveste-se de plena perfeição e eficácia, produzindo todos os efeitos próprios do ato administrativo.

Não existe, "in casu" - assim como na hipótese de apreciação da legalidade dos atos de admissão de pessoal, nos termos do mesmo inciso III do art. 71 da C.F.

49 Revista do TCU, v. 26, n² 63/263-270.

50 RDA 73/140, 80/149, RTFR 101/167, RF 210/183, RT 253/331, 342/189, 477/74, 657/141 e RTJ 77/29.

51 Tribunal de Contas. Registro. Revisão, Saulo Ramos e Hermenito Dourado, RDA 170/197-212

52 Do Ato Administrativo Complexo, Malheiros Editores, 1998.

53 Mandado de Segurança e Direito Público, Ed. RT, 1995, p. 287.

54 RTJ $149 / 323$. 
- apenas "efeitos preliminares ou prodrômicos próprios do ato ainda não submetido a controle" de acordo com a classificação da doutrina ${ }^{5 \leqslant}$. mas verdadeira e plena eficácia. uma vez que o registro, por ser um controle externo independente, não configura aprovação, autorização, homologação ou qualquer outra "conditio juris" integrativa.

Flávio Bauer Novelli, autor que melhor tratou o tema da eficácia do ato administrativo entre nós. ao enumerar os atos que, por estarem sujeitos a controle, têm efeito meramente preliminar. menciona tão-somente aqueles sujeitos " $a$ aprovação. homologação ou visto" "st. E a aposentadoria, em sentido jurídico estrito, não está sujeita a nenhum deles.

É preciso ter em conta que em face da tendência do Estado contemporâneo de generalização do controle a todas as atividades dos poderes ${ }^{57}$, e em razão da significativa ampliação, pela Constituição de 1988, da esfera da competência fiscalizatória dos Tribunais de Contas, não parece razoável subordinar-se a plena eficácia dos atos administrativos ao efetivo controle por essa Corte. Tal entendimento implicaria em cercear a plena eficácia de quase a totalidade dos atos administrativos.

Qual scria, então, a "mens legis" da expressão "para fins de registro", contida no inciso III do art. 71 da Constituição da República?

Entendo que o registro alberga dois objetivos.

O primeiro, conforme Celso Bastos e Ives Gandra Martins, seria "para que seja completado o processo orçamentário, no universo administrativo" " 5 , ficando patente assim o término da missão de controle orçamentário. pela Corte de Contas, no tocante a esse item da despesa. Trata-se, quanto a essa atribuição, de exame posterior das contas, denominado de exame de tipo francês. ${ }^{.5}$

O segundo objetivo seria o de conferir maior estabilidade à aposentadoria, pela importância de que ela se reveste no âmbito público. Coberta sob o manto da coisa julgada administrativa, a aposentadoria não poderia ser alterada unilateralmente, de forma eficaz. pelo órgão que a concedeu.

É o que estabelece a Súmula n 6, do STF. “a revogação ou anulação, pelo Executivo, de aposentadoria, ou qualquer outro ato aprovado pelo Tribunal de Contas, não produz efeitos antes de aprovada por aquele Tribunal, ressalvada a competência revisora do Judiciário."

A Súmula fundou-se especialmente no MS 8.657-ES, relatado pelo Ministro Victor Nunes Leal, sob o argumento, também de Castro Nunes e de Nelson Hungria, no sentido de se negar à Administração a possibilidade de afrontar decisões do órgão de controle externo: "o que ela não pode é anular os atos do Tribunal de Contas." "xi

55 Massimo Severo Giannini, Divitto Amministrativo, Giuffré, 1988, vol. II, p. 711 ; Celso Antônio Bandeira de Mello, Curso de Direito Administrativo, Malheiros Editores, 1995, p. 201.

56 Da eficácia do Ato Administrativo, RDA 60/16-26, 25.

57 Cf. Massino Severo Giannini, op. cit., Vol. I, p. 321.

58 Comentários à Constituição do Brasil, Saraiva, 1997, 4 vol., Tomo II, p. 30.

59 Oswaldo Aranha Bandeira de Mello, op. cit., p. 182.

60 RTJ $20 / 69$. 
Tal Súmula continua sendo aplicada em relação às aposentadorias. como reconheceu recentemente o STF, no MS 22.658-7.". A Administração poderá anular o ato concessório já registrado. mas, no entanto, a anulação somente surtirá efeitos após a concordância do Tribunal de Contas.

Não sendo o registro elemento integrante ou condição de eficácia da aposentadoria. não está obrigado o Tribunal a apreciar um a um os atos concessórios - ou os atos de admissão de pessoal —, mas poderá apreciá-los por amostragem.

Deverá. para tanto. fixar critérios gerais e objetivos de controle externo, de acordo com o que dispuser a sua Lei Orgânica e o seu Regimento Interno. efetuando posteriormente de maneira englobada os registros correspondentes. ${ }^{.2}$

Esse entendimento, aliás, vai ao encontro da viabilidade prática do cumprimento da missão constitucional de registro de todas as admissões de pessoal e aposentadorias. A doutrina vem, torrencialmente, manifestando dúvida a respeito da possibilidade de o Tribunal de Contas ter infra-estrutura para apreciar o elevadíssimo número dos atos previstos no art. 71, inciso III, da Constituição, além de ressaltar tratar-se de atividade inclusive inconveniente, por absorver tempo exagerado no exame de despesas de pequeno porte, em desvio das funções prioritárias do Tribunal. ${ }^{6.3}$

\section{VII - Conclusões}

O fato de não configurar a aposentadoria ato único com o registro (ato complexo), de acordo com todas as razões expostas no presente trabalho, traz várias consequências jurídicas importantes para o aposentado, para o Tribunal de Contas e para a Administração. algumas das quais gostaria de ressaltar.

\section{a) Para o aposentado}

1. A aposentadoria do servidor já é ato perfeito e eficaz a partir de sua publicação, independentemente do seu registro pela Corte de Contas.

$2 \mathrm{O}$ aposentado tem direito ao exercício da prévia e ampla defesa, na hipótese de a Administração pretender cassar-lhe a aposentadoria, ainda que em decorrência de denegação de registro pelo Tribunal de Contas, sob pena de nulidade da cassação.

6) JSTF 236/161.

62 A Lei Orgânica do Tribunal de Contas da Uniāo, Lei 8.443, de 16 de julho de 1992, em seu art. $\mathrm{I}^{2}$, inciso $\mathrm{V}$, prevê que compete ao Tribunal "apreciar, para fins de registro, na forma estabelecida no Regimento Interno" a legalidade dos atos de admissão de pessoal e das concessões de aposentadorias.

63 Pinto Ferreira, Comentários à Constituição Brasileira, Saraiva, 1992, vol. 2 p. 418; Odete Medauar, Controle da Administração Pública, RT, 1993, p. 135; Wolgran Junqueira Freire, Comentários à Constituiçāo de 1988, Ed. Julex, 1989, vol.2, p. 619; Vitor do Amaral Freire, O Tribunal de Contas e sua Jurisdição, Revista do Tribunal de Contas do Rio de Janeiro, jun/82, p. 50. 
3. A cassação de aposentadoria já registrada pelo Tribunal de Contas somente surtirá efeito após a sua aprovação (da cassação) pelo Tribunal de Contas. conforme Súmula 6 do STF.

4. Na interposição de Mandado de Segurança contra alteração ou anulação do ato concessório já registrado, ou cujo registro foi denegado pela Corte de Contas, a autoridade coatora será sempre unicamente a Administração, não cabendo ao Tribunal integrar a lide como litisconsorte necessário.

\section{b) Para o Tribunal de Contas}

1. A decisão sobre a legalidade dos atos concessórios de aposentadoria, para fins de registro, é definitiva e obrigatória na esfera administrativo, revestindo-se da força de coisa julgada administrativa. embora não seja de obrigatoriedade imediata.

2. No procedimento de registro das concessões de aposentadorias, não há a necessidade de chamamento do aposentado para articular a sua defesa.

3. Não está a Corte de Contas obrigada, nos termos constitucionais, a apreciar um a um os atos concessórios de aposentadoria — ou de admissão de pessoal —, mas poderá apreciá-los englobadamente por amostragem, de acordo com critérios gerais e objetivos, previamente fixados.

\section{c) Para a Administração}

1. A anulação ou alteração dos atos concessórios será sempre de exclusiva competência e responsabilidade da Administração.

2. A Administração não está obrigada a acatar imediatamente, como mera executora, a decisão denegatória do registro do Tribunal, mas deverá proferir nova e própria decisão, após assegurar o cumprimento dos ditames constitucionais. inclusive o da ampla defesa.

3. Caso discorde do posicionamento do Tribunal de Contas, deverá, sob pena de responsabilização, recorrer às vias recursais ou revisionais perante aquela Corte, ou à tutela jurisdicional, a fim de fazer prevalecer o seu próprio entendimento, a ser adotado em todos os processos em situação análoga ou similar. 